\title{
Pre-Marital Counseling Effectiveness In Building Happy Muslim Families
}

\author{
Mohammad Nasir ${ }^{*}$, Zainal Abdin 2, Lukman S. Thahir ${ }^{3}$ \\ ${ }^{1}$ Islamic Family Law Department, Postgraduate, Institut Agama Islam Negeri Palu \\ 2 Islamic Family Law Department, Postgraduate, Institut Agama Islam Negeri Palu \\ ${ }^{3}$ Islamic Family Law Department, Postgraduate, Institut Agama Islam Negeri Palu
}

\begin{abstract}
This study discusses the effectiveness of premarital guidance and counseling in building sakinah families at the Office of Religious Affairs (KUA) of Parigi District, Parigi Moutong Regency. The study used qualitative methods and the data was gathered through observation, indepth interviews and written material. The data analysis was analyzed through reduction process, then the data was presented in a table, and it was also verified, and finally the discussion was built based on the data. The results showed that (1) Guidance and premarital counseling in KUA Parigi District has been effectively carried out through premarital counseling and counseling programs carried out through two stages namely the pre-implementation stage and the implementation stage by increasing the role of the counselor in handling divorce, and guidance and pre-marital counseling with procedures that have been determined based on the existing schedule and comprehensive pre-marital guidance materials guided by KUA Employees and several other relevant agencies.
\end{abstract}

\section{ARTICLE \\ INFORMATION}

Keywords:

Ore-Married, counselling, happiness, Muslim families 


\section{Introduction}

Counseling and therapy approaches in premarital education have the greatest impacts in positive changes in the couple's relationship. The couples who voluntarily attend premarital counseling are more united, tend to avoid divorce, and feel satisfaction in marriage relationship.

The family is established through a legal marriage process. In fact, not a few people who already have a prospective husband/wife, are of sufficient age, are already earning, but also don't have the courage to get married because they are not ready. Premarital guidance is needed as a preventive measure so that there are no disputes in the household. ${ }^{1}$

Basically, everyone wants to have a harmonious and happy household (sakinah, mawaddah, warahmah). A family which has full of happiness, love, comfort and inner and outer well-being will certainly have an great influence on the formation of a harmonious society. ${ }^{2}$ But in reality, not all couples are able to achieve it. Building a household is not as easy as turning the palm of the hand, but it takes effort and struggle, because various problems will arise in family life. It could be that problems that arise can be resolved together with deliberation, but not a few also end it in divorce.

${ }^{1}$ Ahmad Zaini, "Membentuk Keluarga Sakinah Melalui Bimbingan dan Konseling Pernikahan" Konseling Religi, Volume 6, Nomor 1 (June 2015), 89-106.

2 See Rusli Rusli, "The Role of Family in Preventing Social Conflict in Society From Islamic Perspectives," HUNAFA: Jurnal Studia Islamika 17, no. 1 (2020): 108-122.
The general provisions are that pre-marriage counseling course are carried out for the Muslim prospective bride and groom who reached at least 19 years old for male and 16 years for female. Most of them are young couples who want to get married, both male and female, and have registered with KUA. However, in principle, pre-marriage course is open to prospective brides and grooms, either those who have failed to build a household with their partner, or those who have not yet wished to get married. As a form of support for their children who are getting married, parents are also expected to accompany their children in participating in the program.

The facilities for organizing premarital guidance include learning facilities, which consist of syllabus, modules, and other teaching materials needed for learning. The syllabus and modules are prepared by the Ministry of Religion to be used as a reference by the organizers of pre-marital guidance. The materials presented include marriage procedures, religious knowledge, laws and regulations in the field of marriage and family.

Basically the marriage is carried out forever until the death of one of the husbands or wives. This is what Islam really wants. However, in certain circumstances, there may be certain things that require the dissolution of the marriage; in a sense that if the marital relationship continues, damage and harm will occur. ${ }^{3}$ In this case, Islam justifies the

${ }^{3}$ Yunus, Haerunnisa, Rusli, Rusli, \& Abidin, Abidin. (2020). The Concept of A e-ISSN: $2715-4580$ p-ISSN: $2715-8268$ 
termination of marriage as the last step in continuing the household. Divorce is a good solution and option in overcoming irreconcilable domestic disputes.

Many couples who, in their first years of marriage, have begun to waver in the ark of their household, because they do not understand the meaning and wisdom of marriage. Divorce nowadays seems to have become a common phenomenon in society. ${ }^{4}$ Many factors may cause divorce including immaturity between husband and wife, economic problems, the presence of third parties in the household, and domestic violence. ${ }^{5}$

\section{Literature Review}

\subsection{Definition of Marriage Counseling} Willis considered marriage counseling as a counseling organized as an educational method to reduce emotional tension, which helps married couples to solve problems and determine better problem solving patterns. It is said to be an educational method because marriage counseling provides insights and knowledge to the couples who consult about themselves, their partners, and marital problems they face as well as

Marriage Agreement in the Compilation of Islamic Law International Journal Of Contemporary Islamic Law And Society, 2(2), 35-45.

${ }^{4}$ For more details about this issue, see Rusli Rusli, "Hermeneutical Reading of Țalāq," HUNAFA: Jurnal Studia Islamika 12, no. 2 (2016): 209-229.

${ }^{5}$ Abdul Ghani Abud, Keluarga Muslim dan Berbagai Masalahnya (Bandung: Perpustakaan Salman, 2008), 104. the ways that can be adopted in overcoming marital problems. ${ }^{6}$

The reduction in emotional tension means that marriage counseling is usually carried out when both parties are in a very emotional situation. With counseling, couples can make ventilation, by opening their emotional channels to the emotional pressures they have faced so far. The one who directs is called the counselor. The councelor is not the subject, because he only helps. The subject is the client, while the object is the problem they face. What can be done by a counselor is, among others, helping clients to understand themselves, measure their abilities, know their readiness and tendencies, clarify their orientations, motivations and aspirations, and know the difficulties and problems of the environment in which they live, as well as the opportunities that are open to them. ${ }^{7}$

\subsection{Marriage Counseling Area}

Problems around marriage or family life usually revolve around the difficulty of choosing a mate, insufficient economy, sharp differences in character between husband and wife, dissatisfaction in sexual relations, and inadequate relationships between extended families. ${ }^{8}$

Marriage counseling was initially carried out not because of the initiative of professionals, but the needs and requests of the couple. They have a number of

\footnotetext{
'Sofyan S. Wilis, Konseling Keluarga (Bandung: Alfabeta, 2009), 56.

${ }^{7}$ Ibid.

${ }^{8}$ Ibid.
} 
problems related to their marriage, and want to consult the problem with a counselor. Marriage counseling has several terms, among others, couples counseling, marriage counseling, and marital counseling. These terms can be used interchangeably and have the same meaning.

\subsection{The Role of Psychological Factors in Marriage}

Psychological factor in marriage is an important element in marriage. Many unexpected things happen in the family due to the following factors:

a. Maturity of Emotions and Thoughts

Emotional maturity and thought will be closely intertwined. Someone who has matured emotionally can usually think clearly, and undergo clear, good, and objective consideration steps. Individuals who are married are legally adults, so they can see the problems that exist in the family well.

b. Developing an attitude of tolerance

Emotional maturity and a person's mindset will make a person able to develop an attitude of tolerance between husband and wife. Being tolerant means developing an attitude of accepting each other's shortcomings and strengths, and respecting their partner. The attitude of tolerance illustrates that each husband and wife must be ready and willing to sacrifice for the interests of the family they have fostered. Cultivating an attitude of tolerance is not an easy matter; however, this needs to be implemented. Of course, this requires mutual understanding from each party. Without an attitude of tolerance between one another, it is impossible for the two individuals to be able to unite well, especially at a young age of marriage, turmoil often occur in the family.

\subsection{The Purpose of Marriage Counseling}

In detail, the long-term goals of marriage counseling according to Huff and Miller ${ }^{9}$ are as follows:

a. Increase self-awareness and mutual empathy between partners.

b. Raise awareness about each other's strengths and potential

c. Increase mutual openness

d. Promote a more intimate relationship

e. Develop communication, problem solving and conflict management skill.

Some assumptions that underlie the implementation of marriage counseling include the following:

a. Marriage counseling emphasizes more on the couple's relationship, not on the personality of each partner.

b. The problem faced by both parties is urgent, so marriage counseling is carried out with a direct approach to solving problems.

c. The problems that couples face are normal problems, not extreme pathological cases.

d. Marriage counseling problems related to types of marriage such as 1) concurrent marital counseling; 2) collaborative Marital counseling; 3)

9 Cited in Brammer, L.M \& Shostrom, E.L. (1982). Therapeutic Psychology: Fundamentals of Counseling and Psychotherapy (Englewood Cliffs, New Jersey: Prentice-Hall, Inc.), 348-349.

e-ISSN: $2715-4580$ p-ISSN: $2715-8268$ 
conjoint marital counseling; 4) couples group counseling. ${ }^{10}$

\subsection{Difficulties and Advantages of Marriage Counseling}

Marriage counseling, in its implementation, is not easy, for several reasons. First, the person being dealt with is problematic, and the problem concerns the relationship between one another. ${ }^{11}$ The counselor must be able to give equal attention to both. Another reason that is often an obstacle in family counseling is that counselors need special skills to handle married couples compared to individual counseling. Marriage counseling requires the ability to pay attention, manage conversations, confrontation skills, and other counseling skills.

Premarital counseling is the counseling held for unmarried parties, in connection with their marriage plans. They usually come to the counselor to make their decisions to be more stable and can make better adjustments in the future. ${ }^{12}$ Aspects that need to be assessed and understood by the counselors when conducting pre-marital counseling are the history of introductions, comparisons of the couple's background, the attitude of the two families, planning for marriage, and psychological and personality factors. ${ }^{13}$

\footnotetext{
10Pujosuwarno Sayekti, Bimbingan Dan Konseling Keluarga (Yogyakarta: Menara Mas Offset, 1994), 98.

11Ibid, 99.

${ }^{12}$ Walgito Bimo, Bimbingan dan Konseling Perkawinan. (Yogyakarta: Andi Offset, 2004), 65. ${ }^{13}$ Ibid.
}

The premarital counseling procedure is similar to that of marriage counseling. What is emphasized in this pre-marital counseling is that it is more anticipatory, which means selfpreparation to make the right choice in relation to the wedding plan. Meanwhile, Family Counseling is a systematic and professional process of counceling for the members, by helping them to develop themselves, connecting the reality of the family with the purpose of its existence, and developing it towards the most suitable for the family and society in relation to the environment in general. ${ }^{14}$

This definition is based on a concept that applies to small groups, especially primary groups. The family is not just a collection of individuals, but a distinctive small group, which is sociologically included in the primary group, or small cell in a multicultural society. ${ }^{15}$

Family guidance needs to pay attention to the distinctive elements of the family as a small group. The dynamics and mastery of the family counselor will determine the success or failure of the assistance process. Based on this definition, it can be stated that the definition contains five essential points in the family, which include acceptance, permissive attitude, functional dynamics, intimate openness, and comprehensive love.

\footnotetext{
14Bimo, Bimbingan, 70.

15Ibid, 66; See also Rusli Rusli, "Multikulturalisme Dalam Wacana Alquran," HUNAFA: Jurnal Studia Islamika 9, no. 1 (2012): 105-120.

e-ISSN: 2715-4580 p-ISSN: $2715-8268$
} 


\section{Methodology}

This study uses qualitative approach $^{16}$ investigating Islamic Law Perspectives on Settlement of inheritance disputes. This research was carried out in Office of Religious Affairs (KUA), subdistrict of Parigi in the District of Parigi Moutong.

Data were collected through observation, indepth interview with married counselors and couples who want to get married and written material ${ }^{17}$. Data analysis consists of several procedures: reduction and verification techniques with various data sources. ${ }^{18}$ The reduced data is then analyzed reflecting on theoretical concepts used in this study ${ }^{19}$.

16 Nurdin, N., \& Yusuf, K. (2020). Knowledge management lifecycle in Islamic bank: the case of syariah banks in Indonesia. International Journal of Knowledge Management Studies, 11(1), 59-80. https://doi.org/10.1504/ijkms.2020.105073; See also Rusli Rusli, "Pendekatan Fenomenologi Dalam Studi Agama Konsep, Kritik Dan Aplikasi," Islamica: Jurnal Studi Keislaman 2, no. 2 (2008): 141-153.

17 Nurdin, Nurdin. (2019). Knowledge Integration Strategy in Islamic Banks. In Almeida Helena \& Sequeira Bernardete (Eds.), The Role of Knowledge Transfer in Open Innovation (pp. 118138). Hershey, PA, USA: IGI Global.

18 Muslih, Imam, Nurdin, Nurdin, \& Marzuki, Marzuki. (2020). Effectiveness of Marriage Services Through Information System Management (SIMKAH) at Palu City Religious Court International Journal of Contemporary Islamic Law And Society, 2(1), 20-35.

19 Iqbal, M., Rusli, R., \& Musyahidah, M. (2019). Management Strategies of Professional Zakat Funds for Mustahiq Family Welfare By Amil Zakat Body International Journal Of Contemporary Islamic Law And Society, 1(1), 39-51.

\section{Result and Discussion}

\subsection{The Effectiveness of Pre-Marriage Guidance and Counseling in Building Harmonious Family}

The Indonesian state, which is based on "the Belief in One God", as the first pillar of Pancasila, only recognizes that legal marriage is established according to religious law as the basis for the formation of a family. Therefore, the Government through related institutions is required to be more proactive in the efforts to strengthen the existence of marriage institutions and preserve the values of marriage.

The method of government efforts in order to improve the quality and value of marriage in a family is to establish a marriage advisory institution that can find solutions to the problems that often arise in the family. The advisory agency is more familiarly known as the Advisory Board for the Development and Preservation of Marriage (BP4).

The Office of Religious Affairs of Parigi District always tries to create a happy marriage and establish a harmonious family. This is in accordance with the vision of BP4 in general, namely to enhance the quality of marriage in order to create a sakinah family according to Islamic teachings in achieving a prosperous Indonesian society and nation both materially and spiritually.

One of the efforts made by the government, in this case, the Ministry of Religion, is the struggle to produce Marriage Law Number 1 of 1974 and establish an institution called BP4. In accordance with Statute of BP4 Article 4, BP4 aims to enhance the value of e-ISSN: $2715-4580$ p-ISSN: 2715-8268 


\section{International Journal of Contemporary Islamic Law and Society}

marriage and create a prosperous and eternal family in accordance with the teachings of Islam. To achieve this goal, the task of The Office of Religious Affairs of Parigi District is to carry out counseling to prospective couples, based on the Marriage Law.

Meanwhile, several efforts were made by the KUA Parigi Subdistrict as one of its programs includes upgrading or providing guidance to prospective brides.

1. Delivering summons to the prospective marriage couples who have registered to take part in the guidance event.

2. Doing pre-marital guidance by the KUA Parigi District once a month which is located at the Office of Religious Affairs of Parigi District.

3. Conducting personal marriage guidance (face to face) for the bride and groom who did not have time to attend at the appointed time.

4. Giving a prosperous family book or magazine to the bride and groom published by BP4.

5. Providing guidance for a prosperous family. ${ }^{20}$

In principle, the duties and objectives of the KUA of Parigi SubDistrict are to reduce the divorce rate and create a sakinah family by preventing early marriage and providing guidance to prospective marriage couples and the community to establish a prosperous and happy family. Meanwhile, the task of religious instructors is a tough task that requires religious instructors to be

${ }^{20}$ Documents of the Office of Religious Affairs of Parigi Subdistrict, 2019. of high quality, both in terms of knowledge and moral quality.

Let alone religious instructors whose job is to enlighten the soul so that clients are able to implement religious teachings. In addition, religious instructors also have the task of providing information and moral development to the community through religious language so that religious people can actively participate in the moral development process so that a sakinah family can be realized in which it is full of Islamic nuances.

The next method used by the KUA of Parigi Sub-District is to make a breakthrough to change the counseling method in such a way, not only with a religious approach, but also providing guidance with all kinds of disciplines. In addition, religious instructors have been more proactive, for example by holding workshops on marriage, and guidance for teenagers, or doing activities for young family groups to provide knowledge and insight that marriage is sacred and religious, so it must be properly cared for. This noble task is always carried out by all KUAs in Indonesia, which include the KUA of Parigi District in particular, as well as improving the quality of marriage and family by developing the sakinah family movement and religious education in the family environment.

Based on an interview with the officer of KUA in Parigi Subdistrict, Muhammad Fadli, who said:

"The implementation of guidance has been carried out by BP4 for a long time, some being carried out in 
groups, and others personally (face to face); or, using the group or personal method, both involve several components from the BKKBN, the Health Office, and local Ulama. If there is anything to do with domestic violence cases, the police must be involved police. So, the purpose in just one; that is, to create a sakinah family" 21

One example is pre-marital guidance, which is usually carried out in the form of course program for the marriage couples (Suscatin). Suscatin is providing knowledge, insights, and skills, and raising awareness to adolescents of marriage age and prospective brides about domestic and family life. Suscatin is usually done one month before the two couples get married, and is carried out simultaneously for prospective brides.

So, the guidance-providing process carried out during pre-wedding is from individual to a group, and the purpose of implementing this guidance or suscatin is to equalize the perception of the institution regarding the substance and mechanism of organizing premarital courses for teenagers and or prospective brides.

Here, what is expected is the realization of a sakinah family; that is, a family that is fostered by a legal marriage, able to meet spiritual and material needs in a proper and balanced way, filled with an atmosphere of affection between family members and

${ }^{21}$ Interview with Muhammad Fadli, officer of KUA, Parigi Subdistrict, 4 October 2019. their environment in harmony, and able to practice, appreciate, and deepen the values of faith, piety and noble character in social life.

Pre-marital guidance (suscatin) is given conditionally considering the number of prospective brides for one month. Pre-marital guidance itself can be done individually or in groups depending on the number of couples who register. For prospective brides who do not have the opportunity to take part in the suscatin program, they can do individual guidance. And, the role of the KUA in Parigi Sub-district in pre-marital guidance and counseling in order to to build a sakinah family in Parigi District KUA is to increase the counselor's role in dealing with divorce.

BP4 is an abbreviation of the Advisory Board for the Development and Preservation of Marriage, which functions as the duty bearer and partner of the Ministry of Religion in realizing a sakinah family. BP4 is an official consulting agency that is part of the Ministry of Religion which acts as an advisory body for marriage guidance, especially for people who will carry out marriages.

In particular, BP4 only deals with the marriage problems of Muslim people, because they need solutions to problems in marriage. Husband and wife often come to the KUA if they have the problem to ask for a solution.

\subsection{Premarital Guidance and Counseling Procedures}

The implementation of marriage guidance at KUA in Parigi Subdistrict is focused on the prospective bride and e-ISSN: 2715-4580 p-ISSN: $2715-8268$ 
groom through pre-marital guidance activities so that they have sufficient knowledge and skills to face family life.

Based on the interviews conducted with several couples of prospective brides, regarding the stages carried out by the bride and groom before carrying out pre-marriage guidance at the KUA in Parigi Subdistrict, one of them said:

“As far as I remember, before doing pre-marital counseling I had to fill out the form provided by the KUA officer. After that, I met other requirements, including a marriage certificate from the village, birth certificate, approval letter for the two prospective brides, a letter from the village about parents, and photo. After all the requirements are complete and registered by the KUA, then I just need to wait for the invitation letter that I will take premarital guidance at the KUA"22

The same is also true for the couples who have taken premarital guidance, such as Ismy Sofyan ${ }^{23}$ and Ismy Syahrul Ramadhan. ${ }^{24}$

From the statements coming from three couples who have attended premarital guidance at KUA in Parigi Subdistrict, it can be concluded that the stages that have been arranged are running properly, and are quite effective for prospective brides who want to

22Interview with Ali Akbar, prospective bride, KUA office, Parigi Subdistrict, 11 October 2019.

${ }^{23}$ Interview with Ismy Sofyan, citizen, KUA office, Parigi Subdistrict, 11 October 2019.

${ }^{24}$ Interview with Ismy Syahrul

Ramadhan, citizen, KUA office, Parigi Subdistrict, 11 October 2019. register themselves and their partners for marriage. Good direction from the Kua in Parigi Subd-district made the stages or processes run well without any shortcomings.

Although the requirements are quite a lot to be fulfilled, such as a marriage certificate from the village, a letter from parents, without good guidance from the KUA, the prospective bride and groom will certainly be confused about meeting the requirements for taking pre-marital guidance. The pre-marriage guidance carried out by the KUA of Parigi Subdstrict aims to provide provisions for prospective brides to be able to create a family that is happy and harmonious (sakinah mawadah warahmah).

\section{a. Premarital Guidance Material}

The material that will be used by the supervisor in conducting guidance process is related to domestic life, marriage law, marriage wisdom, rights and obligations of husband and wife, the way to form a sakinah family and to maintain the integrity of the household to avoid divorce.

The materials presented in premarital guidance at the KUA in Parigi Subdistrict include:

1. Marriage Law and Islamic Laws on marriage (figh al-munakahat)

In the Marriage Law of the Republic of Indonesia Number 1 Year 1947 reads, "Marriage is an inner and outer bond between a man and a woman, as husband and wife with the aim of forming a happy and eternal family (household) based on the Belief on One

e-ISSN: $2715-4580$ p-ISSN: 2715-8268 
God". This statement, at the same time, provides direction so that the married couple should be able to form a safe, peaceful, and happy family.

2). Family planning

Family planning is one of the efforts to realize family happiness and prosperity. Family planning (Keluarga Berencana, KB) is a movement to form a healthy and prosperous family by limiting births. Giving marriage advice regarding family planning programs is one of the efforts to help families plan their family life well so that they can achieve quality families. Based on the interview with the head of KUA in Parigi Subdistrict, it is said:

"The national family planning movement strived to make the community more civilized and independent through the implementation of the Family Planning (KB) counseling program. By improving the quality and convenience of services, while still paying attention to the health of family planning, and is not contradictory with the religious values that exist in society, families are made happy and live in harmony" 25

This kind of counseling material is intended so that the bride and groom can prepare and plan as early as possible their desire to have children, and also to assist them in choosing a family planning device that suits the condition of the wife's body. As for several types of

25Interview with Jumading, Head of KUA, Parigi Subdistrict, 14 October 2019. contraceptives, among others, the pill is usually for mothers who are breastfeeding, injections (1 month and 3 months), implants, IUD (Intrauterine Contraceptive Devices), condoms and tubectomy.

3). Harmonious family

The purpose of marriage in the spiritual aspect is to achieve peace in life that can foster a bond of love (mawaddah) and affection (rahmah) among family members. In realizing the stability of the prospective bride and groom to form a sakinah family, the bride and groom must know the guidelines on how to form a sakinah family according to Islam.

The material presented by the supervisor at the KUA in Parigi Subdistrict when compared to the guidelines for organizing the prospective bride and groom course did not contain the materials psychology of marriage and family, child protection law, domestic violence law. The counselors at KUA, admitted that the material on psychology of marriage and family is not available at KUA because no one has mastered this field and there has been no collaboration between KUA and the authority of this field of psychology. Limited facilities and infrastructure is one factor in the absence of materials on marriage and family psychology in the implementation of premarital guidance at KUA in Parigi Subdistrict.

The statement from the Head of KUA in Parigi Subdistrict was strengthened by the statement of one of his employees as follows:

"In facilitating the process of delivering premarital guidance

e-ISSN: $2715-4580$ p-ISSN: 2715-8268 
materials, a method is needed to support the process of implementing premarital guidance for prospective brides. The method used by the supervisor at KUA in Parigi Subdistrict is the method of lecture and the discussion or question and answer method" 26

The media used in pre-marital guidance at KUA in Parigi District include oral media and certificates behind which there is a summary of the material that has been submitted by the counselor. Although oral media is simple, the material presented is still easily understood by the participants of premarital guidance course. Competent supervisors also support this oral media, making it easier for participants to understand the material presented. Polite speech and vocabulary chosen by the supervisor in conveying the material are also easy for participants to understand.

Premarital guidance is very important given to the bride and groom with the aim that thy can strengthen the relationship after marriage. Premarital guidance has several benefits including running toward a more focused future, reducing the risk of relationship fractures, facilitating the unification of vision, and mutual understanding of the couple's family. This is based on the researcher's interview with one of the KUA employees of Parigi Subdistrict, who said,

"Premarital guidance is very important as a vehicle for guiding two different people to communicate

${ }^{26}$ Interview with Miskiah, officer of KUA, Parigi Subdistrict, 25 October 2019. with each other, learning to solve problems and managing conflict. This skill is clearly very important in one's household life. Young couples really need guidance especially to clarify their expectations for their marriage and strengthen the relationship before marriage. The role of premarital guidance is closely related to the purpose of marriage, to realize a sakinah family in accordance with Islamic religious guidance." 27

The process of implementing marriage guidance for brides and grooms at KUA Parigi Subdistrict has run well and effectively. This is evidenced when researchers go into the field, the process of marriage guidance activities goes smoothly.

\section{Conclusions}

The research concludes that premarital guidance and counseling at the KUA in Parigi Subdistrict has been effectively implemented through the premarital guidance and counseling program carried out in two stages, namely the pre-implementation stage and the implementation stage by increasing the role of the counselor in dealing with divorce, and pre-marital counseling with procedures that have been determined based on the existing schedule and comprehensive pre-marital guidance materials guided by KUA employees and several other relevant agencies.

\section{REFERENCES}

${ }^{27}$ Interview with Iwan, officer of KUA, Parigi Subdistrict, 25 October 2019.

e-ISSN: 2715-4580

p-ISSN: 2715-8268 
Abud, Abdul Ghani. Keluarga Muslim dan Berbagai Masalahnya. Bandung: Perpustakaan Salman, 2008.

Aderahmatillah. Bimbingan dan Konseling Keluarga. Jakarta: Offset, 2007.

Afandi, Ali. Hukum Waris, Hukum Keluarga dan Hukum Pembuktian. Jakarta: Bina Aksara, 1986.

Alamsyah, Fuad. Fikih Nikah Panduan Syar'i Menuju Rumah Tangga Islami. Bandung: PT Syaamil Cipta Media, 2007.

Arikunto, Suharsimi. Manajemen Penelitian. Jakarta: Rineka Cipta, 2005.

Bimo, Walgito. Bimbingan dan Konseling Perkawinan. Yogyakarta: Andi Offset. 2004.

$\mathrm{CH}$, Mufidah. Psikologi Keluarga Islam Berwawasan Gender. Malang, UIN Malang Press

Dabone and Kyeremeh Tawiah. "Effects of Age on Marital Satisfaction of Married People in Sunyani Munippality", International Journal of Research in Social Sciences, Volume 3, No. 8 (April 2014), 48-57.

Daudin, Majid Sulaiman. Hanya untuk Suami. Jakarta: Gema Insani, 1996.

Dirjen Bimbingan Masyarakat Islam, Pembinaan Keluarga Pra Sakinah dan Sakinah I. Jakarta: Depag RI, 2001.

Ezmir. Metodologi Penelitian Kualitatif Analisis Data, 2nd edition. Jakarta: PT. Raja Grafindo Persada, 2011.

Fauzan, M. Pokok-pokok Hukum Islam. Jakarta: PT. RajaGrafindo Persada, 2002.

Ghozali, Abdul Rahman. Fiqh Munakahat. Jakarta: Kencana, 2010
Iqbal, Muhammad, Rusli, Rusli, \& Musyahidah, Musyahidah. (2019). Management Strategies of Professional Zakat Funds for Mustahiq Family Welfare By Amil Zakat Body International Journal of Contemporary Islamic Law And Society, 1(1), 39-51.

Latif. Psikologi Konseling. Malang: Universitas Muhamadiyah Malang, 2006.

M. Idris, Mulyono. Hukum Perkawinan Islam. Jakarta: Bumi Aksara, 1994.

Moleong, Lexy J. Metodologi Penelitian Kualitatif, 17th edition. Bandung: PT. Remaja Rosdakarya, 2002.

Muslih, Imam, Nurdin, Nurdin, \& Marzuki, Marzuki. (2020). Effectiveness of Marriage Services Through Information System Management (SIMKAH) at Palu City Religious Court International Journal of Contemporary Islamic Law And Society, 2(1), 20-35.

Muhammad, Abdul Qadir. Probelamatika Keluarga. Bandung: PT Aditya Bakti, 2012.

Muhibbuddin. Bimbingan dan Konseling Perkawinan. Semarang: Grafika, 2005.

Mustika, M. Shodiq. Doa dan Zikir Cinta: Mengatasi Problema Cinta dari Pranikah hingga Rumah Tangga. Tangerang: QultumMedia, 2009.

Nurdin, Nurdin. (2019). Knowledge Integration Strategy in Islamic Banks. In Almeida Helena \& Sequeira Bernardete (Eds.), The Role of Knowledge Transfer in Open Innovation (pp. 118-138). Hershey, PA, USA: IGI Global. 
Nurdin, Nurdin, \& Yusuf, Khaeruddin. (2020). Knowledge management lifecycle in Islamic bank: the case of syariah banks in Indonesia. International Journal of Knowledge Management Studies, 11(1), 59-80. doi: $10.1504 / \mathrm{ijkms.2020.105073}$

Prabu, Anwar. Manajemen Sumber Daya Manusia Perusahaan. Bandung: Remaja Rosdakarya, 2005.

Prayitno. Dkk, Dasar-Dasar Bimbingan Dan Konseling. Jakarta: PT Rineka Cipta, 1994.

Pujosuwarno Sayekti, Bimbingan Dan Konseling Keluarga. Menara Mas Offset. Yogyakarta, 1994.

Rafiah, Nura. Memecah Kebisuan: Agama Mendengar Korban Kekerasan Perempuan Demi Keadilan. Jakarta : Open Society Institute, 2010.

Rasjid, Sulaiman. Fiqih Islam. Bandung: Sinar Baru Algensindo, 2009.

Ruslan, Rosady. Metode Penelitian Public Relation dan Komunikasi, Cet. IV. Jakarta: PT. Raja Grafindo Persada, 2004.

Rusli Rusli, "Pendekatan Fenomenologi Dalam Studi Agama Konsep, Kritik Dan Aplikasi," Islamica: Jurnal Studi Keislaman 2, no. 2 (2008): 141-153.

Rusli Rusli, "Gagasan Khaled Abu Fadl Tentang "Islam Moderat Versus Islam Puritan (Perspektif Sosiologi Pengetahuan)," Jurnal Ilmiah Ilmu Ushuluddin 8, no. 1 (2009): 99-123.

Rusli Rusli, "Multikulturalisme Dalam Wacana Alquran," HUNAFA: Jurnal Studia Islamika 9, no. 1 (2012): 105120.

R. Rusli, "Progressive Salafism in Online Fatwa," Al-Jami'ah 52, no. 1 (2014): 205-229.
Rusli Rusli, "Hermeneutical Reading of TTalāq," HUNAFA: Jurnal Studia Islamika 12, no. 2 (2016): 209-229.

Rusli Rusli, "The Role of Family in Preventing Social Conflict in Society From Islamic Perspectives," HUNAFA: Jurnal Studia Islamika 17, no. 1 (2020): 108-122.

Iqbal, Muhammad, Rusli, Rusli, \& Musyahidah, Musyahidah. (2019). "Management Strategies of Professional Zakat Funds for Mustahiq Family Welfare By Amil Zakat Body." International Journal of Contemporary Islamic Law and Society, 1(1), 39-51.

Selamat, Kasmuri. Suami Idaman Istri Impian: Membina Keluarga Sakinah. Jakarta: Kalam Mulia, 2007.

Subhan, Zaitunah. Membina Keluarga Sakinah. Yogyakarta: Pustaka Pesantren, 2004.

Sukaenah, Sukaenah, Rusli, Rusli, \& B, M. Taufan. (2020). The Effectiveness of Indonesia Supreme Court Regulation Number 1 Year 2016 Concerning Mediation of Marriage Disputes International Journal Of Contemporary Islamic Law And Society, 2(1), 63-80.

Surakhmad, Winarno. Dasar dan Teknik Research: Pengentar Metodologi Ilmiah. Bandung: Torsito, 1978.

Syaebani, Beni Ahmad. Perkawinan dalam Hukum Islam dan Undang-Undang (Perspektif Fiqih Munakahat dan UU No 1/1974 tentang Poligami dan Problematikanya. Bandung: Pustaka Setia, 2008. 
Tim Penyusun Kamus Pusat Pembinaan dan Pengembangan Bahasa. Kamus Besar Bahasa Indonesia. $3^{\text {rd }}$ edition. Jakarta: Balai Pustaka, 1990.

Undang-Undang No I Tahun 1974 Tentang Perkawinan

Wilis, Sofyan S. Konseling Keluarga. Bandung: Alfabeta, 2009.

Williamson, Hannah C. et.al. "Does Premarital Education Decrease or Increase Couples Later HelpSeeking?" Journal of Family Psychology (December 2, 2013), Accessed 5 March 2019.

Yunus, Haerunnisa, Rusli, Rusli, \& Abidin, Abidin. (2020). The Concept of A Marriage Agreement in the Compilation of Islamic Law International Journal Of Contemporary Islamic Law And Society, 2(2), 35-45.

Zaini, Ahmad. "Membentuk Keluarga Sakinah Melalui Bimbingan dan Konseling Pernikahan" Konseling Religi, Volume 6, No. 1 (June 2015), 89-106. 